MATA KULIAH : BIMBINGAN BELAJAR

NAMA DOSEN : JUSMAWATI, S.Pd., M.Pd

\title{
HASIL EVALUASI BIMBINGAN BELAJAR DAN BIMBINGAN BELAJAR DI MASA PANDEMI COVID 19
}

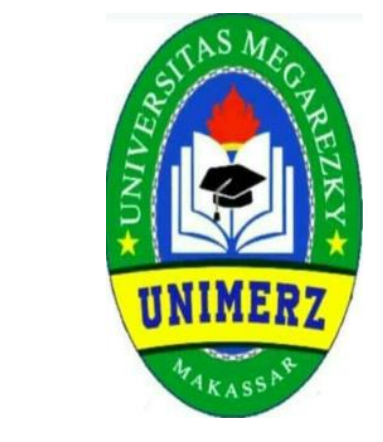

DI SUSUN OLEH :

IRMAYANTI

17093188206015

PENDIDIKAN GURU SEKOLAH DASAR

FAKULTAS KEGURUAN DAN ILMU PENDIDIKAN

UNIVERSITAS MEGAREZKY

2020 


\section{KATA PENGANTAR}

Puji syukur senantiasa kami ucapkan kehadirat Tuhan Yang Maha Esa. Karena atas segala rahmat, petunjuk, dan karunia-Nya sehingga kami dapat menyelesaikan Makalah ini dengan judul Hasil Evaluasi Bimbingan Belajar dan Bimbingan Belajar di Masa Pandemi Covid 19.. Makalah ini dapat digunakan sebagai wahana untuk menambah pengetahuan, sebagai teman belajar, dan sebagai referensi baca.

Ucapan terimakasih kami ucapkan kepada semua yang telah membantu dalam mempersiapkan, melaksanakan, dan menyelesaikan penulisan Makalah ini. Segala upaya telah dilakukan untuk menyempurnakan Makalah ini, namun tidak mustahil apabila dalam Makalah ini masih banyak terdapat kekurangan dan kesalahan. Oleh karena itu, kami mengharapkan kritik dan saran yang dapat dijadikan masukan dalam penyempurnaan Makalah ini.

Semoga Makalah ini dapat bermanfaat bagi kita semua untuk menambah pengetahuan dan wawasan tentang Hasil Evaluasi Bimbingan Belajar dan Bimbingan Belajar di Masa Pandemi Covid 19.

Sapaya, 02 Juni 2020

Penulis 


\section{DAFTAR ISI}

KATA PENGANTAR i

DAFTAR ISI ii

BAB I PENDAHULUAN 1

A. Latar Belakang 1

B. Rumusan Masalah 2

C. Tujuan Penulisan 2

BAB II PEMBAHASAN

A. Pengertian Evaluasi Bimbingan Belajar. 4

B. Fungsi Evaluasi.

C. Aspek-Aspek Yang Dievaluasi. 6

D. Langkah-Langkah Evaluasi.

E. Bimbingan Belajar Pada Masa Pandemi Covid-19. 9

F. Analisis Masalah Belajar dan Solusinya 12

$\begin{array}{ll}\text { G. Motivasi Belajar } & 15\end{array}$

BAB III PENUTUP 19

A. Kesimpulan 19

$\begin{array}{ll}\text { B. Saran } & 19\end{array}$

DAFTAR PUSTAKA $\quad 20$ 


\section{BAB I}

\section{PENDAHULUAN}

\section{A. Latar Belakang}

Agenda pembangunan pendidikan suatu bangsa tidak akan pernah berhenti dan selesai. Ibarat patah tumbuh hilang berganti, selesai memecahkan suatu masalah, muncul masalah lain yang kadang tidak kalah rumitnya. Begitu pula hasil dari sebuah strategi pemecahan masalah pendidikan yang ada, tidak jarang justru mengundang masalah baru yang jauh lebih rumit dari masalah awal. Itulah sebabnya pembangunan bidang pendidikan tidak akan pernah ada batasnya. Selama manusia ada, persoalan pendidikan tidak akan pernah hilang dari wacana suatu bangsa. Oleh karena itu, agenda pembangunan sektor pendidikan selalu ada dan berkembang sesuai dengan dinamika kehidupan masyarakat suatu bangsa.

Evaluasi merupakan subsistem yang sangat penting dan sangat di butuhkan dalam setiap sistem pendidikan, karena evaluasi dapat mencerminkan seberapa jauh perkembangan atau kemajuan hasil pendidikan. Dengan evaluasi, maka maju dan mundurnya kualitas pendidikan dapat diketahui, dan dengan evaluasi pula, kita dapat mengetahui titik kelemahan serta mudah mencari jalan keluar untuk berubah menjadi lebih baik ke depan.

Tanpa evaluasi, kita tidak bisa mengetahui seberapa jauh keberhasilan siswa, dan tanpa evaluasi pula kita tidak akan ada perubahan menjadi lebih baik. Jadi secara umum evaluasi adalah suatu proses sistemik umtuk mengetahui tingkat keberhasilan suatu program. Evaluasi pendidikan dan pengajaran adalah proses kegiatan untuk mendapatkan informasi data mengenai hasil belajar mengajar yang dialami siswa dan mengolah atau menafsirkannya menjadi nilai berupa data kualitatif atau kuantitatif sesuai dengan standar tertentu. Hasilnya

diperlukan untuk membuat berbagai putusan dalam bidang pendidikan dan pengajaran.

Undang-undang Sistem Pendidikan Nasional Nomor 20 tahun 2003 pasal 11 ayat 1 mengamanatkan kepada pemerintah dan pemerintah daerah 
untuk menjamin terselenggaranya pendidikan yang bermutu (berkualitas) bagi setiap warga negara. Terwujudnya pendidikan yang bermutu membutuhkan upaya yang terus menerus untuk selalu meningkatkan kualitas pendidikan. Upaya peningkatan kualitas pendidikan memerlukan upaya peningkatan kualitas pembelajaran (instructional quality) karena muara dari berbagai program pendidikan adalah pada terlaksananya program pembelajaran yang berkualitas. Oleh karena itu, usaha meningkatkan kualitas pendidikan tidak akan tercapai tanpa adanya peningkatan kualitas pembelajaran.

Peningkatan kualitas pembelajaran memerlukan upaya peningkatan kualitas program pembelajaran secara keseluruhan karena hakikat kualitas pembelajaran adalah merupakan kualitas implementasi dari program pembelajaran yang telah dirancang sebelumnya. Upaya peningkatan kualitas program pembelajaran memerlukan informasi hasil evaluasi terhadap kualitas program pembelajaran sebelumnya.

Dengan demikian, untuk dapat melakukan pembaharuan program pendidikan, termasuk di dalamnya adalah program pembelajaran kegiatan evaluasi terhadap program yang sedang maupun telah berjalan sebelumnya perlu dilakukan dengan baik. Untuk dapat menyusun program yang lebih baik, hasil evaluasi program sebelumnya merupakan acuan yang tidak dapat ditinggalkan.

\section{B. Rumusan Masalah}

1. Apa pengertian evaluasi bimbingan belajar?

2. Apa fungsi evaluasi?

3. Apa saja aspek-aspek yang dievaluasi?

4. Bagaimana langkah-langkah evaluasi?

5. Bagaimana bimbingan belajar pada masa pandemi Covid-19?

6. Bagaimana analisis masalah belajar dan solusinya?

7. Apa motivasi belajar?

\section{Tujuan}

1. Untuk mengetahui pengertian evaluasi bimbingan belajar.

2. Untuk mengetahui fungsi evaluasi. 
3. Untuk mengetahui aspek-aspek yang dievaluasi.

4. Untuk mengetahui langkah-langkah evaluasi.

5. Untuk mengetahui bimbingan belajar pada masa pandemi Covid-19.

6. Untuk mengetahui bagaimana analisis masalah belajar dan solusinya.

7. Untuk mengetahui apa saja motivasi belajar. 


\section{BAB II}

\section{PEMBAHASAN}

\section{A. Pengertian Evaluasi Bimbingan Belajar}

Penilaian merupakan langkah penting dalam majemen program bimbingan. Tanpa penilaian keberhasilan atau kegagalan pelaksanaan program bimbingan yang telah direncanakan tidak mungkin diketahui/ diidentifikasi. Penilaian program bimbingan merupakan usaha untuk menilai sejauh mana pelaksanaan program itu mencapai tujuan yang telah ditetapkan. Dengan kata lain bahwa keberhasilan program dalam pencapaian tujuan merupakan suatu kondisi yang hendak dilihat lewat kegiatan penilaian.

Sehubungan dengan penilaian ini, Shetzer dan Stone (1996) mengemukakan pendapatnya bahwa evaluasi adalah kegiatan: "making systematic judgements of the relative effectiveness with which goals are attained in relation to special standards".

Evaluasi dapat pula diartikan sebagai proses pengumpulan informasi (data) untuk mengetahui efektifitas (keterlaksanaan dan ketercapaian kegiatankegiatan yang telah dilaksanakan dalam upaya mengambil keputusan. Pengertian lain dari evaluasi ini adalah suatu usaha untuk mendapatkan berbagai informasi secara berkala, bekesinambungan dan menyeluruh tentang proses dan hasil dari perkembangan sikap dan perilaku atau tugas-tugas perkembangan para siswa melalui program kegiatan yang telah dilaksanakan.

Bimbingan adalah proses interaksi antara pembimbing dengan yang dibimbing baik secara langsung maupun tidak langsung dalam rangka untuk membantu peserta didik agar dapat mengembangkan potensi dirinya ataupun memecahkan permasalahan yang dialaminya.

Sedangkan adapun pengertian belajar menurut Jusmawati dan Eka Fitriana (2019: 25) Belajar adalah suatu proses usaha yang dilakukan seseorang untuk memperoleh suatu perubahan tingkah laku yang baru secara keseluruhan, sebagai hasil pengalamannya sendiridalam interaksi dengan lingkungannya. 
Sehingga dapat saya simpulkan bahwa evaluasi bimbingan belajar adalah suatu usaha untuk mendapatkan atau mengetahui tentang proses dan hasil perkembangan peserta didik melalui kegiatan-kegiatan yang telah dilaksanakan.

Penilaian kegiatan bimbingan di sekolah adalah segala upaya, tindakan atau proses untuk menentukan derajat kualitas kemajuan yang berkaitan dengan pelaksanaan program bimbingan di sekolah dengan mengacu pada kriterteria atau patokan-patokan tertentu sesuai dengan program bimbingan yang dilaksanakan.

Kriteria atau patokan yang dipakai untuk menilai keberhasilan pelaksanaan program layanan bimbingan dan konseling di sekolah adalah mengacu pada terpenuhi atau tidak terpenuhinya kebutuhan-kebutuhan siswa dan pihak-pihak yang terlibat baik langsung maupun tidak langsung berperan membantu siswa memperoleh perubahan perilaku dan pribadi kearah yang lebih baik.

Dalam keseluruhan kegiatan layanan bimbingan dan konseling, penilaian diperlukan untuk memperoleh umpan balik terhadap kefektivan layanan bimbingan yang telah dilaksanakan. Dengan informasi ini dapat diketahui sampai sejauh mana derajat keberhasilan kegiatan layanan bimbingan. Berdasarkan informasi ini dapat ditetapkan langkah-langkah tindak lanjut untuk memperbaiki dan mengembangkan program selanjutnya.

\section{B. Fungsi Evaluasi}

1. Memberikan umpan balik (feed back) kepada guru pembimbing (konselor) untuk memperbaiki atau mengembangkan program bimbingan dan konseling.

2. Memberikan informasi kepada pihak pimpinan sekolah, guru mata pelajaraan dan orang tua siswa tentang perkembangan siswa, agar secara bersinergi atau berkolaborasi meningkatkan kualitas implementasi program BK di sekolah. 


\section{Aspek-Aspek yang Dievaluasi}

Ada dua macam aspek kegiatan penilaian program kegiatan bimbingan, yaitu penilaian proses dan penilaian hasil. Penilaian proses dimaksudkan untuk mengetahui sampai sejauh mana kefektivan layanan bimbingan dilihat dari prosesnya, sedangkan penilaian hasil dimaksudkan untuk memperoleh informasi kefektifan layanan bimbingan dilihat dari hasilnya. Aspek yang dinilai baik proses maupun hasil antara lain :

1. Kesesuaian antara program dan pelaksanaan,

2. Keterlaksanaan program,

3. Hambatan-hambatan yang dijumpai,

4. Dampak layanan bimbingan terhadap kegiatan belajar mengajar,

5. Respon siswa, personil sekolah, orang tua dan masyarakat terhadap layanan bimbingan,

6. Perubahan kemajuan siswa dilihat dari pencapaian tujuan layanan bimbingan, pencapaian tugas-tugas perkembangan dan hasil belajar, dan keberhasilan siswa setelah menamatkan sekolah baik pada studi lanjutan maupun pada kehidupan di masyarakat.

Apabila dilihat dari sifat evaluasi, evaluasi bimbingan dan konseling lebih bersifat "penilaian dalam proses" yang dapat dilakukan dengan cara berikut ini:

1. Mengetahui partisipasi dan aktifitas siswa dalam kegiatan layanan bimbingan.

2. Mengungkapkan pemahaman siswa atas bahan-bahan yang disajikan atau pemahaman/pendalaman siswa atas masalah yang dihadapinya.

3. Mengungkapkan kegunaan layanan bagi siswa dan perolehan siswa sebagai hasil dari partisipasi atau aktifitasnya dalam kegiatan layanan bimbingan.

4. Mengungkapkan minat siswa tentang perlunya layanan bimbingan lebih lanjut.

5. Mengamati perkembangan siswa dari waktu ke waktu (butir ini terutama dilakukan dalam kegiatan layanan bimbingan yang berkesinambungan).

6. Mengungkapkan kelancaran proses dan suasana penyelenggaraan kegiatan layanan. 
Berbeda dengan hasil evaluasi pengajaran yang pada umumnya berbentuk angka atau skor, maka hasil evaluasi bimbingan dan konseling berupa deskripsi tentang aspek-aspek yang dievaluasi (seperti partisipasi/ aktivitas dan pemahaman siswa, kegunaan layanan menurut siswa, perolehan siswa dari layanan, perkembangan siswa dari waktu ke waktu, perolehan guru pembimbing, komitmen pihak-pihak terkait, serta kelancaran dan suasana penyelenggaraan kegiatan). Deskripsi tersebut mencerminkan sejauh mana proses penyelenggaraan layanan/pendukung memberikan sesuatu yang berharga bagi kemajuan dan perkembangan dan atau memberikan bahan atau kemudahan untuk kegiatan layanan terhadap siswa.

\section{Langkah-langkah Evaluasi}

Dalam melaksanakan evaluasi program ditempuh langkah sebagai berikut :

1. Merumuskan masalah atau beberapa pertanyaan. Karena tujuan evaluasi adalah untuk memperoleh data yang diperlukan untuk mengambil keputusan, maka konselor perlu mempersiapkan pertanyaan-pertanyaan yang terkait dengan hal-hal yang akan dievaluasi. Pertanyaan-pertanyaan itu pada dasarnya terkait dua spek pokok yang dievaluasi yaitu : (1) tingkat keterlakasanaan program (aspek proses) dan (2) tingkat ketercapaian tujuan program (aspek hasil).

2. Mengembangkan atau menyusun instrumen pengumpul data. Untuk memperoleh data yang diperlukan yaitu mengenai tingkat keterlak- asanaan dan ketercapaian program, maka konselor perlu menyusun instrumen yang relevan dengan kedua aspek tersebut. Instumen itu diantaranya inventori, angket, pedoman wawancara, pedoman observasi dan studi dokumentasi.

3. Mengumpulkan dan menganalisis data. Setelah data diperoleh maka data itu dianalisis, yaitu menelaah tentang program apa saja yang telah dan belum dilaksanakan, serta tujuan mana daja yang telah dan belum tercapai.

4. Melakukan tindak lanjut (follow up). Berdasarkan temuan yang diperoleh, maka dapat dilakukan kegiatan tindak lanjut. Kegiatan ini dapat meliputi dua kegiatan yaitu: 
a. memperbaiki hal-hal yang dipandang lemah, kurang tepat atau kurang relevan dengan tujuan yang ingin dicapai.

b. mengembangkan program, dengan cara merubah atau menambah beberapa hal yanh dipandang dapat meningkatkan efektivitas atau kualitas program.

Penilaian di tingkat sekolah merupakan tanggung jawab kepala sekolah yang dibantu oleh pembimbing khusus dan personel sekolah lainnya. Disamping itu penilaian kegiatan bimbingan dilakukan juga oleh pejabat yang berwenang (pengawas bimbingan dan konseling) dari instansi yang lebih tinggi (Departemen Pendidikan Nasional Kota atau Kabupaten).

Sumber informasi untuk keperluan penilaian ini antara lain siswa, kepala sekolah, para wali kelas, guru ,mata pelajaran, orang tua, tokoh masyarakat, organisasi profesi bimbingan, sekolah lanjutan dan sebagianya. Penilaian dilakukan dengan menggunakan berbagai cara dan alat seperti wawancara, observasi, studi dokumentasi, angket, tes, analisis hasil kerja siswa dan sebagainya.

Penilaian perlu diprogramkan secara sistematiis dan terpadu. Kegiatan penilaian baik mengenai proses maupun hasil perlu dianalisis untuk kemudian dijadikan dasar dan tindak lanjut untuk perbaikan dan pengembangan program layanan bimbingan. Dengan dilakukan penilaian secara komprehensip, jelas dan cermat maka diperoleh data atau informasi ini dapat disajikan bahan untuk pertanggungjawaban/ akuntabilitas pelaksanaan program bimbingan dan konseling. Secara skematis evaluasi program bimbingan dan konseling tersebut dapat digambarkan pada lampiran 3. Pengawas melakukan pembinaan dan pengawasan dalam bentuk mendorong konselor layanan bimbingan dan konseling untuk melakukan evaluasi program dan keterlaksanaan program. Minimal evaluasi dilakukan pada akhir tahun ajaran dan menjdi salah satu dasar pengembangan program untuk tahun ajaran berikutnya. Evaluasi proses sebaiknya dilakukan setiap bulan melalui forum pertemuan staf (MGBK di sekolah) dan dapat dihadiri oleh unsur pimpinan sekolah. Konselor dapat mengembangkan instrument yang dapat menjaring umpan balik secara 
triangulasi yaitu dari siswa sebagai objek dan subjek bimbingan, dari pendidik di sekolah sebagai person yang terlibat dan berinteraksi langsung dengan siswa. Dokumen pelaksanaan evaluasi menjadi salah satu indicator untuk kerja konselor.

\section{E. Bimbingan Belajar di Masa Pandemi Covid 19}

Pandemi Covid-19 berdampak besar pada berbagai sektor, salah satunya pendidikan. Dunia pendidikan juga ikut merasakan dampaknya. Pendidik harus memastikan kegiatan belajar mengajar tetap berjalan, meskipun peserta didik berada di rumah. Solusinya, pendidik dituntut mendesain media pembelajaran sebagai inovasi dengan memanfaatkan media daring (online).

Ini sesuai dengan Menteri Pendidikan dan Kebudayaan Republik Indonesia terkait Surat Edaran Nomor 4 Tahun 2020 tentang Pelaksanaan Kebijakan Pendidikan dalam Masa Darurat Penyebaran Corona Virus Disease (Covid-19).

Sistem pembelajaran dilaksanakan melalui perangkat personal computer (PC) atau laptop yang terhubung dengan koneksi jaringan internet. Pendidik dapat melakukan pembelajaran bersama di waktu yang sama menggunakan grup di media sosial seperti WhatsApp (WA), telegram, instagram, aplikasi zoom ataupun media lainnya sebagai media pembelajaran.

Dengan demikian, pendidik dapat memastikan peserta didik mengikuti pembelajaran dalam waktu bersamaan, meskipun di tempat yang berbeda. Pendidik pun dapat memberi tugas terukur sesuai dengan tujuan materi yang disampaikan kepada peserta didik.

Kondisi pandemi Covid-19 ini mengakibatkan perubahan yang luar biasa, termasuk bidang pendidikan. Seolah seluruh jenjang pendidikan 'dipaksa' bertransformasi untuk beradaptasi secara tiba-tiba drastis untuk melakukan pembelajaran dari rumah melalui media daring (online). Ini tentu bukanlah hal yang mudah, karena belum sepenuhnya siap. Problematika dunia pendidikan yaitu belum seragamnya proses pembelajaran, baik standar maupun kualitas capaian pembelajaran yang diinginkan. 
Berbagai aplikasi media pembelajaran pun sudah tersedia, baik pemerintah maupun swasta. Pemerintah mengeluarkan Surat Edaran Menteri Pendidikan dan Kebudayaan Nomor 9/2018 tentang Pemanfaatan Rumah Belajar. Pihak swasta pun menyuguhkan bimbingan belajar online seperti ruang guru, Zenius, Klassku, Kahoot, dan lainnya.

Akses-akses tersebut dapat dimanfaatkan untuk mengembangkan pengetahuan danwawasan. Sangat diperlukan peningkatan kualitas sumber daya manusia (SDM). Keberhasilan pembangunan negara salah satu tolak ukurnya adalah keberhasilan pendidikan.

Melalui pendidikan, akan melahirkan generasi penerus yang cerdas intelektual maupun emosional, terampil, dan mandiri untuk mencapai pembangunan bangsa ini.Namun muncul polemik masyarakat pada metamorfosa di masa pandemi Covid-19.

Hal ini tentu dirasa berat oleh pendidik dan peserta didik. Terutama bagi pendidik, dituntut kreatif dalam penyampaian materi melalui media pembelajaran daring. Ini perlu disesuaikan juga dengan jenjang pendidikan dalam kebutuhannya. Dampaknya akan menimbulkan tekanan fisikmaupun psikis (mental). Pola pikir yang positif dapat membantu menerapkan media pembelajaran daring, sehingga menghasilkan capaian pembelajaran yang tetap berkualitas. Belajar di rumah dengan menggunakan media daring mengharapkan orangtua sebagai role model dalam pendampingan belajar anak, dihadapi perubahan sikap.

Masa pandemi Covid-19 ini bisa dikatakan sebagai sebuah peluang dalam dunia pendidikan, baik pemanfaatan teknologi seiring dengan industri 4.0, maupun orangtua sebagai mentor. Harapannya, pasca-pandemi Covid-19, kita menjadi terbiasa dengan sistem saat ini sebagai budaya pembelajaran dalam pendidikan.

Wabah Covid-19 ditetapkan sebagai pandemi global dan BNPB menetapkan status darurat nasional. Berkaitan dengan hal tersebut pemerintah telah melakukan upaya preventif guna mencegah dan meminimalkan penyebaran virus tersebut. Kebijakan yang diambil pemerintah Indonesia yaitu 
dengan menerapkan social distancing atau menjaga jarak dan Work From Home (WFH) baik pegawai negeri maupun swasta sejak Maret lalu. Kebijakan ini mempunyai beberapa implikasi pada berbagai bidang, tidak terkecuali bidang pendidikan.

Menteri Pendidikan dan Kebudayaan RI Nadiem Anwar Makarim merespon dengan kebijakan belajar dari rumah melalui pembelajaran daring. Padahal, interaksi guru dan siswa dalam proses pembelajaran sangat penting untuk mengetahui kemajuan proses belajar siswa. Hal ini menjadi tantangan bagi guru agar berinovasi dalam proses pembelajaran secara daring, tak terkecuali guru BK. Guru BK dituntut untuk tetap melakukan konseling walaupun tidak dengan face to face seperti yang biasanya dilakukan. Lalu media apa saja yang mungkin dapat digunakan guru Bimbingan dan Konseling selama pandemi covid19? Guru Bimbingan dan Konseling dalam memberikan layanan kepada siswa binaannya dengan menggunakan inovasi baru sesuai dengan era revolusi industri 4.0 dan tidak mengesampingkan protokol kesehatan.

1. Menggunakan media Whatsaap. Media ini dapat dipergunakan dalam memberikan layanan bimbingan kelompok kepada peserta didik atau konseli dengan mudah tanpa dibatasi ruang dan waktu. Begitu juga buat para orang tua siswa yang sibuk bekerja bisa mendapatkan layanan ini dan bisa dijangkau dimanapun mereka berada.

2. Media website bimbingan. Ini salah satu media yang dapat menampilkan halaman-halaman yang digunakan untuk menampilkan informasi teks, gambar diam atau bergerak, animasi maupun suara yang bisa diakses oleh siapapun termasuk siswa.

3. Media cybercounseling. Guru Bimbingan dan Konseling dapat memberikan layanan lewat dunia maya menggunakan dan memanfaatkan video call di jejaring sosial. Dengan model konseling ini, konselor dan konseli tetap dapat bertatap muka dan berkomunikasi lisan sebagai inti dari konseling. Konseling melalui cyber ini konselor juga dapat menunjukkan empati dan 
perhatian penuh pada konseli, melihat gerak-gerik konseli dan saling berkomunikasi sacara verbal.

4. Media Elektronic- counseling. E- konseling melalui media internet secara umum merujuk pada profesi yang berkaitan dengan layanan kesehatan mental melalui teknologi komunikasi internet. Yang perlu dipersiapkan dalam electronic counseling yang mendasar adalah konselor dan konseli harus memiliki paket internet yang memadai.

\section{F. Analisis Masalah Belajar dan Solusinya}

Masalah adalah suatu keadaaan yang tidak diharapkan oleh kita sebagai penyimpangan kecil dalam bidang kehidupan yang kita alami. Permasalahan yang timbul akibat adanya berbagai faktor yakni faktor internal dan faktor eksternal. Masalah atau problem dalam pembelajaran sangatlah mungkin, dan ini bisa disebabkan oleh beberapa faktor, bisa dari peserta didik sendiri atau dari pengajar (guru).

1. Faktor Internal

Faktor ini meliputi gangguan psiko fisik siswa, yakni :

a. Yang bersifat kognitif seperti rendahnya rendahnya kapasitas intelektual.

b. Yang bersifat afektif antara labilnya emosi dan sikap. Kelemahan emosional, seperti merasa tidak aman, kurang menyesuaikan diri serta ketidakmatangan emosi.

c. Yang bersifat psikomotor antara lain terganggunya alat indra, cacat tubuh, serta kurang berfungsinya organ-organ perasaan.

d. Motivasi. Kurangnya motivasi belajar akan menyebabkan anak atau siswa malas untuk belajar.

e. Konsentrasi belajar yang kurang baik.

f. Rasa percaya diri. Rasa percaya diri timbul dari keinginan berhasil dalam belajar.

g. Kebiasaan belajar. Kebiasaan belajar akan mempengaruhi kemampuannya dalam berlatih da menguasai materi yang telah disampaikan oleh guru. 
h. Kurang perhatian dan minat terhadap pelajaran sekolah, malas dalam belajar, dan sering bolos atau tidak mengikuti pelajaran.

2. Faktor eksternal

Faktor ini meliputi semua situasi dan kondisi lingkungan siswa yang tidak kondusif bagi terwujudnya aktifitas-aktifitas belajar. Yang termasuk dalam faktor ini adalah :

a. Lingkungan keluarga, seperti ketidak harmonisan hubungan antara ayah dan ibu, dan rendahnya tingkat ekonomi keluarga.

b. Lingkungan masyarakat, seperti wilayah yang kumuh, teman sepermainan yang nakal.

c. Lingkungan sekolah, seperti kondisi dan letak gedung sekolah yang buruk, seperti dekat pasar kondisi guru, serta alat-alat belajar yang berkualitas rendah.

d. Guru sebagai pembina siswa belajar. Guru adalah pengajar yang mendidik. Dia tidak hanya menajar bidang studi yang sesuai dengan keahliannnya, tetapi juga menjadi pendidik pemuda generasi bangsa.

e. Kurikulum sekolah. Adanya kurikulum baru akan menimbulkan masalah seperti tujuan yang akan dicapai mungkin juga berubah, isi pendidikan berubah, kegiatan belajar mengajar juga berubah serta evaluasi berubah.

f. Terlalu berat beban belajar siswa maupun guru.

g. Metode belajar yang kurang memadai.

h. Sikap orangtua yang tidak memperhatikan anaknya.

i. Keadaan ekonomi.

Mengatasi malas belajar siswa agar bersemangat dan tidak malas untuk belajar, adalah hal yang harus dilakukan oleh orangtua di rumah maupun guru di sekolah. Terkadang siswa malas untuk belajar karena minat dan motivasi yang kurang dari orangtua maupun guru. Orangtua maupun guru harus mendukung dan memotivasi siswa agar bersemangat dan tidak malas untuk belajar. Ada beberapa solusi yang bisa dilakukan oleh orangtua maupun guru untuk meningkatkan minat belajar siswa adalah sebagai berikut : 
1. Menanamkan pengertian yang benar tentang belajar pada siswa sejak dini, menumbuhkan inisiatif belajar mandiri pada siswa, menanamkan kesadaran serta tanggung jawab sebagai pelajar pada siswa merupakan hal lain yang bermanfaat jangka panjang.

2. Berikan contoh belajar pada peserta didik.

3. Berikan intensif jika siswa belajar. Intensif yang dapat diberikan ke siswa tidak selalu berupa materi, tapi bisa juga berupa penghargaan dan perhatian.

4. Orang tua sering mengajukan pertanyaan tentang hal-hal yang diajarkan di sekolah pada anak. Sehingga orangtua tahu perkembangan anak di sekolah.

5. Mengajarkan kepada siswa pelajaran-pelajaran dengan metode tertentu yang sesuai dengan kemampuan siswa.

6. Komunikasi. Orangtua harus membuka diri, berkomunikasi dengan anak untuk mendapat informasi tentang perkembangan anak tersebut.

7. Menciptakan disiplin. Jadikan belajar sebagai rutinitas yang pasti.

8. Menciptakan suasana belajar yang baik dan nyaman, orangtua memberikan perhatian dengan cara mengarahkan dan mendampingi anak saat belajar.

9. Menghibur dan memberikan solusi yang baik dan bijaksana pada anak, apabila anak sedang sedih atau sedang sakit, sedang tidak ada motivasi untuk belajar, orangtua harus membangun motivasi anak agar bersemangat dalam belajar.

10. Gunakan imajinasi peserta didik. Orangtua membantu peserta didik membayangkan apa yang dia inginkan untuk masa depan, baik dalam waktu panjang atau pendek.

11. Mengarahkan peserta didik untuk berteman dan hidup dalam lingkungan yang baik dan mendukung.

12. Tidak memfokuskan bahwa belajar hanya dari buku saja. Tetapi dari lingkungan sekitar juga dapat digunakan untuk belajar.

13. Mengidentifikasi siswa yang diperkirakan mengalami kesulitan dalam belajar. 
14. Membangun motivasi atau minat belajar siswa, sehingga siswa bersemangat dalam belajar.

15. Menyiapkan ruang kelas yang nyaman, kondusif, sehingga siswa dapat belajar dengan nyaman.

16. Guru dalam mengajar harus melibatkan anak secara aktif melalui kegiatan diskusi, tugas kelompok agar anak tidak bosan di dalam kelas. Karena metode guru yang mengajar dengan berceramah saja akan membuat siswa merasa bosan dan tidak memperhatikan.

17. Guru harus mempunyai model pembelajaran yang bervariasi dalam setiap pertemuan agar tidak monoton, sehingga siswa semangat dengan metode pembelajaran yang baru.

18. Melakukan pendekatan terhadap siswa.

\section{G. Motivasi Belajar}

1. Pengertian Motvasi Belajar

Menurut Jusmawati dkk dalam bukunya (2018: 103-106) Motivasi adalah perubahan energi hearts diri deseorang yang ditandai dengan timbulnya perasaan dan reaksi untuk review mencapai tujuan. Dengan pengertian ini, dapat dikatakan bahwa motivasi adalah sesuatu yang kompleks. Motivasi akan menyebabkan terjadinya energi yang ada pada diri manusia, dan akan bergayut dengan mengeluarkan gejala-gejala, perasaan dan juga emosi, untuk kemudian atau melakukan sesuatu.

Motivasi adalah sesuatu yang dibutuhkan untuk melakukan aktivitas. Motivasi secara umum yaitu sebagai dorongan yang muncul pada diri seseorang atau tidak sadar, untuk melakukan tindakan dengan tujuan tertentu. Sedangkan secara psikologis, berarti usaha yang dapat menghasilkan seseorang atau kelompok orang tergerak melakukan sesuatu karena ingin mencapai tujuan yang dikehendakinya, atau mendapat kepuasan dengan perbuatannya. (KBBI, 2001: 756).

Dari beberapa pendapat di differences, dapat diambil kesimpulan bahwa pengertianmotivasi adalah keseluruhan daya penggerak baik dari hearts diri maupun dari luar dengan creates serangkaian usaha untuk review 
menyediakan kondisi-kondisi tertentu yang menjamin kelangsungan dan memberikan arah pada aktivitas sehingga tujuan yang dikehendaki oleh subjek itu dapat tercapai .

\section{Cara Meningkatkan Motivasi Belajar Anak SD}

Sebagai seorang pendidik anak di sekolah dasar (SD), tentu Anda sering mengamati wajah-wajah siswa Anda yang tampak murung dan tidak memiliki motivasi belajar. Hal ini bisa Anda amati dengan memperhatikan gerak-gerik mereka seperti tidak mengerjakan pekerjaan rumah, malas mengerjakan tugas ketika di sekolah, tidak merespons pertanyaan dari guru, tidak berperan aktif di dalam kelas, dan sering berkomentar menarik perhatian orang lain. Jika ada siswa Anda yang demikian, tentu akan cukup mengganggu proses belajar mengajar di kelas. Sebagai orang tua mereka di sekolah, Anda wajib untuk memberikan kata-kata motivasi untuk anak sd, cerita motivasi untuk anak sd, materi motivasi untuk anak sd, contoh motivasi untuk anak sd, serta motivasi belajar untuk anak sd. Berikut ada beberapa cara guru memotivasi siswa sd yang mungkin bisa Anda terapkan kepada siswa Anda.

a. Tidak pelit akan pujian

Sudah sepantasnya sebagai seorang guru, Anda memberikan pujian kepada siswa-siswi Anda yang berprestasi di kelas. Pujian ini bisa Anda tunjukkan dengan memberikan komentar positif dibuku tugasnya dengan kalimat pujian, namun jangan hanya menuliskan tulisan „,bagus ${ }^{\text {ee }}$ saja melainkan kerja yang bagus, tingkatkan terus prestasimuee. Sering memberikan pujian atas prestasi siswa akan membuat siswa merasa istimewa di mata gurunya.

Membentuk kebiasaan belajar yang baik Tugas Anda sebagai guru tentu memberikan pengetahuan baru kepada para siswa. Berikanlah cara belajar baru yang baik dan benar baik ketika siswa tersebut sedang belajar sendiri maupun berkelompok. Dengan cara demikian nantinya para siswa akan lebih termotivasi dalam mengulang- 
ulang pelajaran ataupun menambah pemahaman baru dengan bukubuku yang mendukung.

b. Ciptakan pesaingan atau kompetisi

Buatlah semacam kompetisi yang sehat di dalam kelas yang diikuti oleh para siswa agar dapat meningkatkan prestasi belajar mereka. Hal ini juga dapat membuat mereka sadar dan mempunyai rasa ingin memperbaiki hasil prestasi yang dicapai sebelumnya.

c. Menulis nama siswa di papan tulis

Cara selanjutnya yang dapat meningkatkan motivasi belajar siswa sd dan membuat mereka merasa istimewa adalah dengan menuliskan nama mereka di papan tulis. Gambarlah bintang di sebelah nama mereka yang menunjukkan hasil prestasi belajar mereka.

d. Gunakan media belajar yang baik dan sesuai

Media pembelajaran biasanya digunakan sebagai alat bantu dalam proses belajar mengajar. Segala sesuatu yang ada di sekitar Anda sesungguhnya dapat Anda manfaatkan untuk merangsang pikiran, kemampuan, keterampilan belajar, serta perhatian sehingg dapat mendorong terjadinya proses belajar. Media belajar ini umumnya sangat banyak, mulai dari yang harganya murah hingga mahal, dan dari yang sederhana hingga rumit. Media belajar ini juga dapat Anda buat sendiri jika anda memilih untuk tidak membelinya. Beberapa media belajar yang akrab digunakan para guru seperti video, cd audio, dan lainnya.

e. Menjelaskan tujuan belajar

Setiap dimulainya proses belajar, sebaiknya Anda menjelaskan terlebih dahulu tentang tujuan pembelajaran yang akan dicapai oleh siswa. Tak hanya itu saja, Anda juga bisa memberikan penjelasan tambahan seperti mengutarakan tentang pentingnya belajar bagi seseorang untuk masa depannya, dan masih banyak lagi. Umumnya semakin jelas tujuan yang Anda utarakan kepada siswa maka makin besar pula motivasi belajar siswa tersebut. 
f. Memberikan poin kelompok

Poin kelompok merupakan cara ketujuh yang bisa Anda lakukan dalam meningkatkan motivasi belajar siswa di kelas serta menumbuhkan jiwa kepemimpinan dan kerjasama. Caranya mudah. Bentuklah kelompok kompetisi saat anda ingin memberi pertanyaan pada siswa. bisa 1 sampai 10 atau 10 sampai 100 sesuai kebutuhan. Poin tak hanya untuk kelompok yang dapat menjawab pertanyaan, tapi dapat juga diberikan ketika Anda fokus pada managemen kelas, misalnya kelompok yang paling rajin, kompak, atau bersemangat.

g. Memberikan ulangan atau ujian secara berkala

Para siswa secara tidak langsung akan dituntut untuk giat belajar jika mengetahui akan diadakan ulangan. Tetapi ada baiknya ulangan ini jangan terlalu sering dilakukan karena akan cukup membosankan dan akan sekedar jadi rutinitas belaka.

h. Menumbuhkan kesadaran siswa

Menumbuhkan kesadaran kepada siswa agar merasakan pentingnya tugas dan menerimanya sebagai tantangan sehingga bekerja keras adalah sebagai salah satu bentuk motivasi yang cukup penting. Bentuk kerja keras siswa dapat terlibat secara kognitif yaitu dengan mencari cara untuk dapat meningkatkan motivasi.

i. Memberikan dorongan kepada siswa untuk belajar

Anda bisa memberikan dorongan ini dengan cara memberikan perhatian yang maksimal kepada siswa, khusunya bagi mereka yang prestasinya cukup rendah. Anda sebagai guru dituntut untuk lebih jeli terhadap kondisi anak didik Anda. 


\section{BAB III \\ PENUTUP}

\section{A. Kesimpulan}

Evaluasi adalah proses pengumpulan informasi (data) untuk mengetahui efektifitas (keterlaksanaan dan ketercapaian kegiatan-kegiatan yang telah dilaksanakan dalam upaya mengambil keputusan. Pengertian lain dari evaluasi ini adalah suatu usaha untuk mendapatkan berbagai informasi secara berkala, bekesinambungan dan menyeluruh tentang proses dan hasil dari perkembangan sikap dan perilaku atau tugas-tugas perkembangan para siswa melalui program kegiatan yang telah dilaksanakan.

Penilaian kegiatan bimbingan di sekolah adalah segala upaya, tindakan atau proses untuk menentukan derajat kualitas kemajuan yang berkaitan dengan pelaksanaan program bimbingan di sekolah dengan mengacu pada kriterteria atau patokan-patokan tertentu sesuai dengan program bimbingan yang dilaksanakan.

Pandemi Covid-19 berdampak besar pada berbagai sektor, salah satunya pendidikan. Dunia pendidikan juga ikut merasakan dampaknya. Pendidik harus memastikan kegiatan belajar mengajar tetap berjalan, meskipun peserta didik berada di rumah. Solusinya, pendidik dituntut mendesain media pembelajaran sebagai inovasi dengan memanfaatkan media daring (online).

Ini sesuai dengan Menteri Pendidikan dan Kebudayaan Republik Indonesia terkait Surat Edaran Nomor 4 Tahun 2020 tentang Pelaksanaan Kebijakan Pendidikan dalam Masa Darurat Penyebaran Corona Virus Disease (Covid-19).

\section{B. Saran}

Dengan adanya pembuatan makalah ini penulis mengharapkan agar senantiasa dapat dimanfaatkan dan sebagai literatur atau sebagai bahan rujukan bagi mahasiswa dalam menambah wawasan pengetahuannya. Sehingga mampu memberikan kontribusi dalam proses pembelajaran dan pendidikan. 


\section{DAFTAR PUSTAKA}

Jusmawati dan Fitriana HS, Eka. 2019. Manajemen Kelas. Serang-Banten: CV. AARIZKY

Jusmawati, Satriawati dan Irman R. 2018. Strategi Belajar Mengajar. Jalan Kesatuan 3: Rizky Artha Mulia

https://radarsemarang.jawapos.com/rubrik/untukmu-guruku/2020/05/27/media(diakses pada tanggal 03 Juni 2020)

https://www.asikbelajar.com/evaluasi-bimbingan-dan-konseling-di/ (diakses pada tanggal 03 Juni 2020)

https://afidburhanuddin.wordpress.com/2014/05/19/masalah-belajar-dansolusinya/ (diakses pada tanggal 04 Juli 2020) 
